\title{
EMOTIONAL INTELLIGENCE AND THE SENSE OF EFFICIENCY OF COACHING AND INSTRUCTING IN WRESTLING
}

\author{
Emotional intelligence in wrestling
}

\author{
KATARZYNA RUTKOWSKA ${ }^{1}$, DARIUSZ GIERCZUK ${ }^{2}$ \\ The Josef Pilsudski University of Physical Education in Warsaw, \\ Faculty of Physical Education and Sport in Biała Podlaska, Department of Psychology \\ Department of Sports Theory and Disabled People's Sport ${ }^{2}$
}

\author{
Mailing address: Katarzyna Rutkowska, Faculty of Physical Education and Sport, 2 Akademicka Street, \\ 21-500 Biała Podlaska, tel.: +48 83 3428779, fax: +48 83 3428800, e-mail: kr@psychologsportu.pl
}

\begin{abstract}
Introduction. The aim of this study was to diagnose the level of emotional intelligence and sense of efficiency among the occupational group of coaches and instructors in wrestling. Material and methods. The study involved 27 participants of a training course for coaches and instructors in training ( 25 men and 2 women). The basic methods of research involved the Emotional Intelligence Questionnaire INTE and the GSES scale for measurement of the sense of efficacy. Their use allowed us to diagnose the average level of emotional intelligence and the sense of self-efficacy. Results. Coaches and instructors are characterised by average level of emotional intelligence and the sense of self-efficacy. First class coaches are characterized by significantly higher levels of emotional intelligence, and the belonging to the group of trainers has no influence on the sense of efficacy. Conclusions. The results of the study can provide guidance to create/modify training programs for sports coaches. Developing mental toughness and improving emotional intelligence should occupy a special place in the training process wrestlers.
\end{abstract}

Key words: emotional intelligence, sense of efficacy, wrestling

(...) we are not just educating coaches but people who work as coaches (...) [Perkowski 2009, p. 179]

\section{Introduction}

The specificity of the work of a contemporary coach in the sport needs constant development and enhancement of interdisciplinary skills. Knowledge of various fields and the ability to apply it under specific circumstances, increase the efficacy of coaches. One such field is psychology. Being aware of his/her own psychosocial needs and those of the players and a coach not only continually enhances his/her knowledge in this field, but also cares about personal development, fine tunes various skills/competencies that might guarantee effective and satisfactory performance in various spheres of life - professional as well as personal. One of the important elements of social competence is emotional intelligence.

Wrestling is one of the most difficult sports discipline [1, 2]. It requires high level of physical fitness and appropriate personality traits [3, 4]. During competition, wrestlers use variety of technical and tactical actions to overcome the resistance of the opponent. Actions conducted in this way are characterized by rapid change of position and multiplicity of unexpected changes in the situation [5, 6, 7]. The result of direct sports combat of two wrestlers, often equally well-trained in terms of fitness, depends largely on their mental toughness and connected with it emotional intelligence, i.e. the ability to tackle new tasks and adapt to the changing situation during hard physical exertion and fatigue. Appropriate level of mental preparation largely determines the extent of success and attaining perfection in wrestling $[1,2,8]$.
A well-trained wrestler should have the potential ability to cope with a variety of difficult situations arising during the process of training and competition. Without proper mental preparation it would be difficult to make the right decisions, perform appropriate activities, perceive cause and effect relationships in sports training, elimination of erroneous actions and ways of solving tasks [8]. Therefore, in the process of training of wrestlers, training focused on shaping mental resilience and improvement of emotional intelligence is an absolute necessity.

The traditional academic psychology assumes that the concept of intelligence characterizes the level of intellectual functioning. This applies only to the cognitive aspect of human activity. Emotions (especially those of representatives of the cognitive mainstream) are treated as an irrational element, interfering/lowering the level of intellectual functioning [9]. Relatively recent studies, however, led to the conclusion that high IQ, not only is not sufficient, but sometimes even hinders the attainment of goals. The search for determinants of comprehensive human development, effective functioning in various areas and various successes, intra-/interpersonal good relationships and, consequently, satisfaction with life helped to successfully raise the profile of emotional intelligence $[9,10$, $11]$.

Emotional intelligence is an acquired meta-skill (acquired especially in childhood). At the same time, it is worth noting, in a sense it moderates the acquisition of social skills and development of various competencies, mainly including empa- 
thy - i.e. a component of emotional intelligence. Emotional intelligence is a collection of instrumental and motivational skills, which helps to effectively utilize the human potential. It determines the adequate processing of emotional knowledge, perception, understanding and regulating emotions. Its high level provides comprehensive access to the emotions also during the process of thinking. Thanks to emotional intelligence the use of existing emotional experience becomes more effective, which in turn proves to be helpful in coping with difficult social situations $[11,12,13]$. The results also show that the level of emotional intelligence is significantly associated with broadly defined health - good frame of mind in different areas of human functioning. Emotionally intelligent individuals cope better with difficult situations, and more effectively manage stress [14]. It therefore appears that in this sense the level of emotional intelligence is related to the sense of human self efficacy. The sense of self-efficacy is identified with the conviction of one's own competency, control of their own actions, and even a sense of internal locus of control. It is treated as a psychological resource - a subjective belief in the possibility of affecting the course of various types of situations - both known ones and new ones. In practice, it is reflected at the stage of undertaking of an activity and a possible revision of its course. People with a higher sense of self-efficacy, aware of their resources and their impact on situations, are more eager to undertake various activities (even if marked by risk) and more effectively pursue their objectives $[15,16,17,18,19]$.

Emotional intelligence understood in this way and sense of self-efficacy should be the main characteristics of a modern coach. A person, who understands and optimally manages their own emotions and those of the protégées, assists the development of their psychological resources through that of his/her own, yet is aware of his/her completeness and successfully implements certain assumptions (personal as well as the training/professional ones).

\section{Material and methods}

The purpose of this study was to determine the level of emotional intelligence and sense of self-efficacy, and a possible relationship between these variables in the occupational group of coaches and instructors in wrestling. The results may be helpful in developing guidelines for preparation/modification of programmes for sports instructors, especially in the area of education/training in psychology. The expected effect of implemented changes will involve improvement in specific psychosocial predispositions/skills; and ultimately - more effective interaction with players.

In the study, an individually prepared questionnaire was used, which involved the collection of basic particulars as well as basic information about the career of the coach/instructor. In addition, the subjects were also asked to complete:

- Emotional Intelligence Questionnaire INTE - an accurate and reliable tool conceptually related to the theoretical model of emotional intelligence of Salovey and Mayer, the questionnaire consists of 33 statements to which subjects respond by determining the degree (on five-point scale ), given the wording of compliance with their convictions [13],

- GSES scale - Generalized Self-Efficacy Scale - by Schwarzer, Jerusalem and Juczyński used for measurement of the sense of self efficacy [17].

The study involved 27 people. They were students of educational courses for wrestling coaches/trainers organized by the Faculty of Physical Education in Biala Podlaska (AWF Warszawa). The study was conducted in two stages, during which 15 students of first class coach training course were tested (14 men, 1 woman) and 12 students (11 men, 1 woman) instructor's course.

The subjects $(\mathrm{N}=27)$ were aged $18-53$ years. The characteristics of each group are as follows: first-class coaches $-\mathrm{M}=38.3$, $\mathrm{SD}=7.15$, instructors $-\mathrm{M}=28.3, \mathrm{SD}=10.0$, the difference is statistically significant $(\mathrm{U}=34.5, \mathrm{p} \leqslant 0.01)$. The subjects had various level of experience in training and working with players, and the average length of experience was in the group of fist class couches was $-\mathrm{M}=11.1, \mathrm{SD}=7.1$, and in the group of instructors $-\mathrm{M}=1.7, \mathrm{SD}=2.1$ (it is worthwhile emphasizing that five instructors had not yet worked in the profession, while the length of professional experience of the others ranged from 1 year to 7 years). This variable was also different in both groups $-U=7.0, p \leqslant 0.01$.

\section{Results}

After gathering research material, appropriate calculations were made, just as required by the authors of the tools. Unprocessed results were referred to the appropriate standards (including gender and age of the respondents in the case of measurement of emotional intelligence, and in the case of the sense of self-efficacy the results were referred to the interim standards for all adults) for each person to give so-called calculated results. Analysis of the averaged converted results leads to the conclusion that coaches and instructors represent the average level of emotional intelligence and the average level of self efficacy. It should also be noted that (based on the nonparametric test of significance between the ranks of U MannWhitney) first class coaches had higher levels of emotional intelligence than the instructors. The results of detailed analyses are presented in Table 1.

Table 1. Analysis of the level of emotional intelligence and self-efficacy surveyed coaches and trainers

\begin{tabular}{|c|l|c|c|c|c|c|}
\hline $\begin{array}{c}\text { Scale } \\
\text { and type } \\
\text { of results }\end{array}$ & Surveyed group & $\begin{array}{c}\text { Results } \\
\text { interval }\end{array}$ & $\mathbf{M}^{2}$ & $\mathbf{S D}^{3}$ & $\mathbf{U}^{4}$ & $\mathbf{P}^{5}$ \\
\hline \multirow{2}{*}{ INTE - WS } & First class coaches & $117-154$ & 138.3 & 9.22 & \multirow{2}{*}{30.0} & 0.00 \\
\cline { 2 - 6 } & Instructors & $110-137$ & 125.7 & 8.4 & & \multirow{2}{*}{0.00} \\
\hline \multirow{2}{*}{ INTE - WP } & First class coaches & $4-10$ & 7.9 & 1.4 & \multirow{2}{*}{29.5} & 0.00 \\
\cline { 2 - 6 } & Instructors & $3-8$ & 5.7 & 1.6 & & \multirow{2}{*}{0.39} \\
\hline \multirow{2}{*}{ GSES - WS } & First class coaches & $29-39$ & 33.7 & 3.4 & & \multirow{2}{*}{0.5} \\
\cline { 2 - 6 } & Instructors & $29-36$ & 32.4 & 2.5 & & \multirow{2}{*}{0.43 .5} \\
\hline \multirow{2}{*}{ GSES - WP } & First class coaches & $6-10$ & 7.9 & 1.3 & & \\
\cline { 2 - 6 } & Instructors & 6.9 & 7.5 & 0.9 & & \\
\hline
\end{tabular}

WS - raw data, WP - calculated results, raw score each subject were referred to the ten standards proposed by the authors of the tools - on this basis the results were averaged;

${ }^{2}$ Mathematical average; ${ }^{3}$ Standard deviation;

${ }^{4}$ U Mann-Whitney test result; ${ }^{5}$ significance level

Moreover, referring to the indications in the literature, a statement of categories of calculated results was prepared, showing the level of emotional intelligence. Figure 1 presents the percentage distribution of the three basic categories. In the group of first class coaches there were no low scores. Nearly $70 \%$ of the subjects obtained high scores. In the group of instructors one person had a score showing emotional intelligence level being below average. Two people received high scores, others, $3 / 4$ of the group, were at the average level of the tested variable. 


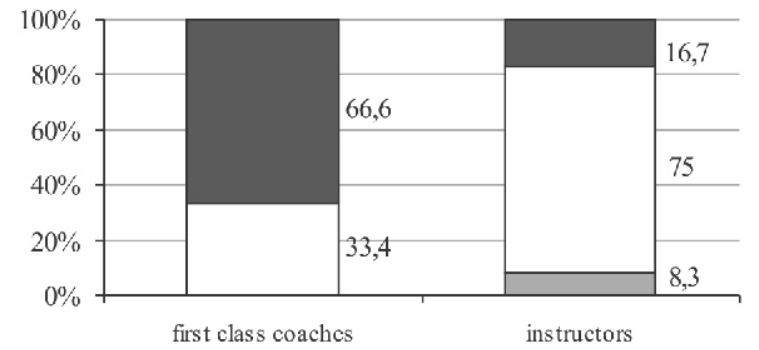

$\square$ low (1-3 sten) $\square$ average (4-7 sten) $\square$ high (8-10 sten)

Figure 1. Presentation of categories of calculated results INTE

A similar analysis was prepared for the results of the survey respondents using the GSES Scale (Fig. 2). All the respondents obtained results showing the average and higher than average level of the sense of self-efficacy, there were no low results. Among the first class coaches there were two people, and among the instructors - one person, obtained average results. The rest of the respondents - being vast majority - had high levels of the sense of self-efficacy.

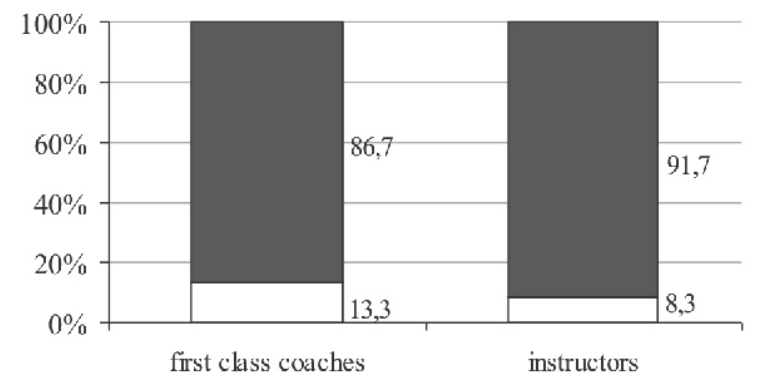

$\square$ kw (1-4 sten) $\square$ average (5-6 sten) $\square$ high (7-10 sten)

Figure 2. Presentation of categories of calculated results GSES

The next step in the statistical analysis was to calculate correlation. Referring to the value of rho-Spearman coefficients it was demonstrated that in the group of first class coaches there was a correlation between the level of the sense of self efficacy and the level of emotional intelligence $(r h o=0.60, p \leqslant 0.05)$. In addition, a relationship was identified between age of coaches and the length of their involvement in the profession $(r h o=0.73, p \leqslant 0.01)$. No such relationships were found in the group of instructors. On the other hand, when analyzing the test results, a correlation between age and the sense of self-efficacy was revealed ( $r h o=0.61, p \leqslant 0.05$ ), which in turn was not found in the group of trainers.

\section{Discussion}

The findings can be viewed in two different ways. The significance of emotional intelligence and the sense of self-efficacy appears to be important (considered as separate characteristics, but also related variables), as much for the coach as for his/her players. The coach is for them not only a trainer but also an educator. Presented by his skills are kind of role model for pupils.

However, it appears that the deliberate and conscious strengthening of emotional intelligence among athletes is not yet sufficiently appreciated. The literature suggests that it is worthwhile to dedicate appropriate thematic blocks to this issue (for example, ones developed by sports psychologists).
Emotional intelligence allows players to make better use of various psychosocial skills, useful in sporting situations, but also in personal life. Examples of such skills (which are highly conducive to the optimization of self-regulation) include more positive inner monologues, which are a kind of buffer between the emotions and reactions $[14,20]$. This easily translates into sporting results [21]. A coach who is also a leader should not only develop players' emotional resistance, but also support them emotionally. Research shows that genuine concern demonstrated to athletes translates into their commitment to training [22]. This may be particularly important in the context of the growing problem - the resignation of young people from sport, as well as professional satisfaction in the context of the coach [23]. However, observation of the reaction of many coaches (especially during the competition of their players) not always provides optimistic conclusions [24].

Currently, more and more attention is paid to the issue of coaching. This issue is closely related to the area of sport $[25,26,27]$. It is suggested that the coach, which in practice is a trainer, should enhance emotional intelligence in others, but for this to be possible he should intensely care about his/her personal development [28]. And so, the second direction of the discussion of our own research is the importance of the variables tested for the functioning of the coach. In sports psychology of sport, there increasingly appear analyses of the psychological profile of coach [24, 29, 30,31]. A coach who has high level of specific psychological skills (including perhaps those analysed in this study) "can effectively form players' confidence and their belief in success" [30]. In light of this thesis, the research brings optimistic forecasts. The vast majority of the respondents (instructors as well as coaches) are characterized by high level of the sense of self-efficacy. On the other hand, the difference in the levels of emotional intelligence between the two groups may become an important guideline for developing of sports coach training programs. At the level of institutional education of instructors more attention must be devoted to issues related to psychosocial development to strengthen and to direct the development of social competence with particular reference to the component discussed in this study, and at the same time, in conjunction therewith, the sense of self-efficacy should be reinforced. Assuming that the trainers gain knowledge and skills on the basis of institutional interaction (usually these are training courses increasing of formal qualifications or occasional thematic training), and in the course of independent activity [32], it is worthwhile to consider the third option (in addition to formal education and self education), which monitoring would ensure institutional learning outcomes and support personal and professional development - a form even more considering the elements of sports psychology [25]. Psychologists are offered so-called supervisions $[33,34]$, health care workers use the so-called Balint training enhancing self-awareness, empathy improvement, which translates into better performance in the personal and professional life [35, 36]. Perhaps the professional group of instructors/trainers could also receive customized and new forms of training suited to the specifics of their work individual needs.

The consequences of deficiencies in the field of emotional intelligence, particularly empathy, may even increase the likelihood of aggressive behaviour [37]. It is worth noting that empathy never reaches perfection. It requires constant reinforcement. Working on it favourably affects the quality of interaction with others [38]. This may be an argument for the implementation of programs developing selected psychological and social skills among high level coaches who have been in the profession for extended periods of time. "The own self is born during the interaction with other people. Depending on what was the quality of interaction with them, the chances of self 
affirmation and consolidation either increase or decrease" [38]. This in turn is important in the context of another problem professional burnout among coaches. It is the body's response to chronic occupational stress and failures in dealing with various types of burdens. It is worth noting that the probability of its occurrence is higher among people who strongly identify with their professional roles, and are highly involved in what they do [39]. Burnout, emotional exhaustion, depersonalization, feelings of personal achievement are other symptoms that indicate this process $[40,41,42,43]$. A number of negative consequences of burnout involve not only the work area and working relationships. The effects can be felt in the area of relationships with loved ones and in the family environment. Burnout syndromes include deterioration of relationships, decreased interest in the problems of family etc. [39, 41]. The issue of professional burnout was originally discussed mainly in the context of a group of nurses and teachers. The conclusion of these discussions can be very useful in the case of sports, namely - for trainers and coaches, especially that in the literature more often this issue is being raised - both in terms of coaches (and professional burnout) and athletes (sports burnout; also at the level of children and youth sports) [44, 45, 46]. Of particular interest are the studies in which the issue of burnout analyzed from two different prospective. The authors demonstrate a link between the professional burnout of coaches and sporting burnout of players [47]. Providing coaches with specific psychological skills, raising their awareness of psychosocial needs of their own and those of the player, making them aware of certain problems (including risk) and raising awareness and the ability to identify (in themselves and their players) psychological resources, including emotional intelligence (which is believed to be a buffer against professional burnout) and the sense of self-efficacy, and encouraging the pursuit of personal development, should be strongly emphasized in training programs for sports coaches and trainers.

It is worth noting that the majority of respondents already had professional experience in the coaching job. In this group there were also seven persons - participants of the instructor's training course. This is a proof that also people who do not yet have formal qualifications also work as coaches; this group of candidates for instructor has an average of nearly three years professional experience. Five people from the group of instructors did not have any work experience at the time of the study. This fact, as well as the age of the subjects, may have contributed to the lack of correlation between the emotional intelligence and the sense of self-efficacy among the instructors, whereas such a link was noted in the group of coaches. Not only the high level of specific variables (for example, emotional intelligence test), but also their relationship to other psychological resources (such as sense of self-efficacy) can contribute to more effective professional and personal development. Such relationships can form naturally in the course of social training, based on life experiences (personal and professional experience). However, they should be parallel, systemically and directionally amplified and directed in the course of formal education. People who prepare educational professional development programs should take into account the fact that among those entering the path of professional coaching development there will be newcomers to the profession as well as people with several years of experience. This is another premise supporting the above proposals to implement additional forms of development allowing for some individualization.

The increase sporting level in wrestling forces trainers continuous improvement of knowledge about mental resilience, and methods for improving various psychological resources, including - emotional intelligence of players. Unfortunately, the issue of emotional intelligence in the process of training of wrestlers is usually ignored, and its formation primarily takes place as a "by product" of training, for example on the basis of gaining further sporting experience.

The necessity to provide players in the training process with adequate set of skills to cope in a variety of unforeseen situations, under extreme pressure and physical as well as emotional exhaustion is absolutely undisputed. However, without continuous upgrading of knowledge, skills and relevant qualifications it may be very difficult. Specialized courses for instructors and coaches, workshops, scientific and methodological and training should cover appropriate number of hours equip trainers/coaches with the necessary knowledge and skills to improve their emotional intelligence and that of players. Unfortunately, wrestling training programs lack appropriate emphasis on mental preparation, including the presentation of methods for developing mental toughness and ability of coaches and athletes to cope in a variety of problematic situations. Even the recent changes in the new legislation implemented by Minister for Sport and Tourism regarding the obtaining of professional qualifications in sport include no provisions for the implementation extended training in sports psychology. It is disproportionate to the seriousness of the importance of emotional intelligence in competition and achieving high performance of athletes, especially in direct contact sports.

The research conducted for the purpose of this study covered relatively small group of training staff, including only two women - which seems to confirm that the profession of coaching is represented mainly by men, with only every tenth coach in Poland being a woman $[48,49]$. The general selection of the sample is justified by non mass training of coaching staff in wrestling, and the still low popularity of wrestling. Nevertheless, especially in the face of changes in education instructors and coaches, the results of this study can become a contribution to the debate on the issues of psychosocial aspects of general development and professional development.

\section{Conclusions}

Based on the information obtained, the following conclusions were made:

1. Coaches and instructors are characterized by average level of emotional intelligence and the sense of selfefficacy.

2. First class coaches are characterized by significantly higher levels of emotional intelligence.

3. Belonging to a group of trainers has no effect on the sense of self-efficacy.

4. Developing mental toughness and connected with it emotional intelligence should occupy a special place in the wrestlers training process. 


\section{Literature}

1. Kruszewski, A. (2004). Wrestling - the Basics of Training Theory and Practice. Warszawa: COS. [in Polish]

2. Sadowski, J. \& Gierczuk, D. (2009). Correlations between selected coordination motor abilities and technical skills of Greco-Roman wrestlers aged 14-15. Arch. Budo 5, 35-39.

3. Barbas, I., Kouli O., Bebetsos E., Mirzaei B. \& Curby D.G. (2011). The relationship between emotions and confidence among wrestling athletes in Greece. Int. J. Wrestling Science 1(1), 33-42.

4. Gierczuk, D. (2008). Level of selected indicators of coordination motor abilities in greco-roman and freestyle wrestlers aged 13-14. Pol. J Sport Tourism 15(4), 192-199.

5. Daugs, R. et al. (1991). Teaching and technical improvements in theory and practice. In R. Daugs et al. (Eds.), Teaching and technical improvements. (pp. 19-32). Schorndorf: Hofmann. [in German]

6. Kühn, J. (1985). Research on improving the technical coordination of young wrestlers fight. Theorie und Praxis der Körperkultur 11, 848-854. [in German]

7. Sadowski, J. \& Gierczuk D. (2010). Effectiveness of coordination training in technical preparation of freestyle wrestlers at various levels of sports advancement. Arch. Budo 6, 143-148.

8. Gracz, J. \& Sankowski T. (2000). Sports psychology. Poznań: AWF. [in Polish]

9. Maruszewski, T. \& Ścigała E. (1998). Emotions, alexithymia, knowledge. Poznań: Wydawnictwo Fundacji Humaniora. [in Polish]

10. Golińska, L. (2002). Please understand, I'm sorry to hurt you. Charaktery 11, 32-33. [in Polish]

11. Salovey, P. \& Sluyter D.J. (Eds.) (1999). Emotional development and emotional intelligence. Educational problems. Poznań: Dom Wydawniczy Rebis. [in Polish]

12. Goleman, D. (1997). Emotional Intelligence. Poznań: Media Rodzina. [in Polish]

13. Jaworowska, A. \& Matczak A. (2001). Emotional intelligence questionnaire. Handbook. Warszawa: Pracownia Testów Psychologicznych PTP. [in Polish]

14. Schutte, N.S., Malouff J.M., Thorsteinsson E.B., Bhullar N. \& Rooke S.E. (2007). A metaanalytic investigation of the relationship between emotional intelligence and health. Pers. Indiv. Differ. 42, 921-933.

15. Bandura, A. (1997). Self-efficacy: The Exercise of Control. New York: H. Freeman.

16. Buckworth, J. \& Dishman R.K. (2007). Exercise adherence. In G. Tenenbaum \& R.C. Eklund (Eds.), Handbook of sport psychology (pp. 509-536). New Jersey: John Wiley \& Sons.

17. Juczyński, Z. (2001). Measurement Tools in the Promotion and Psychology of Health. Warszawa: PTP. [in Polish]

18. Schwarzer, R. (1997). Self-efficacy in taking and continuation of health behaviours. The existing theoretical approaches and a new mode. In I. Heszen-Niejodek \& H. Sęk (Eds.), Health psychology (pp. 175-206). Warszawa: PWN. [in Polish]

19. Zimbardo, P.G. (1999). Psychology and Life. Warszawa: PWN. [in Polish]

20. Lane, A.M., Thelwell R.C., Lowther J. \& Devonport T.J. (2009). Emotional intelligence and psychological skills use among athletes. Soc. Behav. Pers. 37, 195-202.

21. Crombie, D., Lombard C. \& Noakes T. (2009). Emotional intelligence scores predict team sports performance in a national cricket competition. Int. J. Sport Sci. Coach. 4, 209-224.

22. Larson, A. (2006). Student perception of caring teaching in physical education. Sport Educ. Soc. 11, 337-352.
23. Naylor, A. (2007). EQ versus IQ in the athletic training clinical environment. Athletic Therapy Today 12, 39-41.

24. Herzig, M. (2002). Psychological factors and skills and the effectiveness of a coach. Sport Wyczynowy 5-6, 23-31. [in Polish]

25. Brewer, B.W. (2000). Doing sport psychology in the coaching role. In M.B. Andersen (Ed.), Doing sport psychology (pp. 237-247). Champaign: Human Kinetics.

26. Panfil, R. (2007). Coaching a Skilled Player. Wrocław: Akademia Umiejętności Management \& Coaching. [in Polish]

27. Włodarczyk, P. \& Ziółkowski A. (2010). Coaching as a tool to support player development. In M. Krawczyński (Ed.), Children and youth sorts psychology (pp. 213-22). Gdańsk: Pomorska Federacja Sportu. [in Polish]

28. Neale, S., Spencer-Arnell L. \& Wilson L. (2010). Emotional intelligence coaching. Warszawa: Wolters Kluwer Polska. [in Polish]

29. Gould, D., Greenleaf C., Guiñan D. \& Chung Y. (2002). A survey of U.S. Olympic coaches: Variables perceived to have influenced athlete performances and coach effectiveness. The Sport Psychologist 16, 229-250.

30. Nowicki, D. (2010). Psychological skills of a coach and their application in the training and competitive process. Sport Wyczynowy 2, 104-113. [in Polish]

31. Rutkowska, K. (2006). The level of social competence of coaches and sports instructors. In D. Parzelski (Ed.), Psychology in sports - theory, research and practice (pp. 70-83). Warszawa: UW. [in Polish]

32. Perkowski, K. (2009). Improvement of Professional Competence Trainers competitive sports in Poland. Warszawa: AWF. [in Polish]

33. Andersen, M.B., Van Raalte J.L. \& Harris G. (2000). Supervision II: a case study. In M.B. Andersen (Ed.), Doing sport psychology (pp. 167-179). Champaign: Human Kinetics.

34. Van Raalte, J.L. \& Andersen M.B. (2000). Supervision I: from models to doing. In M.B. Andersen (Ed.), Doing sport psychology (pp. 153-165). Champaign: Human Kinetics.

35. Łazowski, J. (2002). Balint group training. Polska Medycyna Rodzinna 4, 31-34. [in Polish]

36. Wasilewski, B. \& Engel L. (2011). Balint group training. Theory and application. Warszawa: Eneteia, Wydawnictwo Psychologii i Kultury. [in Polish]

37. Czerniawska, M. (2002). Empathy and the system of value. Przeglad Psychologiczny 45(1), 7-18. [in Polish]

38. Mellibruda, J. (1980). I-you-we. Psychological Possibilities of Improving Relations among People. Warszawa: Nasza Księgarnia. [in Polish]

39. Sapilak, B.J. \& Steciwko A. (2002). Professional burnout predispositions, symptoms, prevention. Polska Medycyna Rodzinna 4, 337-341. [in Polish]

40. Makara-Studzińska, M. \& Płotka A. (1997). The syndrome of professional burnout. Pielęgniarka i Położna 6, 4-5. [in Polish]

41. Maslach, Ch. (2000). Professional burnout - multidimensional prospects. In H. Sęk (Ed.), Professional burnout the reasons, mechanism, prevention (pp. 13-31). Warszawa: PWN. [in Polish]

42. Szlendak, B. (2002). Symptoms mechanisms and causes of professional burnout of nurses. Pielęgniarka i Położna 7, 18-21. [in Polish]

43. Tucholska, S. (2001). The concept of professional burnout according to Christina Masalach: development stages. Przeglad Psychologiczny 44(3), 301-317. [in Polish]

44. Cashmore, E. (2002). Sport Psychology. The Key Concepts. London, New York: Routledge, Taylor \& Francis Group.

45. Eklund, R.C. \& Cresswell S.L. (2007). Athlete burnout. In G. Tenenbaum \& R.C. Eklund (Eds.), Handbook of sport psychology (pp. 621-641). New Jersey: John Wiley \& Sons. 
46. Łuszczyńska, A. (2011). Psychology of Sport and Physical Activity. Clinical Issues. Warszawa: PWN. [in Polish]

47. Vealey, R.S., Armstrong L., Comar W. \& Greenleaf C.A. (1998). Influence of perceived coaching behaviours on burnout and competitive anxiety in female college athletes. J. Appl. Sport Psychol. 10, 279-38.

48. Kowalczyk, D. (1996). Coaching staff in Poland. Trening 2, 43-52. [in Polish]

49. Kamień, D. (2003). Female coach - a voice in discussion. In J. Kłodecka-Różalska (Ed.), A sportswoman is a successful woman ... Benefits and barriers to women's sports activities (pp. 159-160). Warszawa: Polskie Stowarzyszenie Sportu Kobiet, Instytut Sportu. [in Polish]

Submitted: June 30, 2011

Accepted: January 24, 2012 